\title{
KOMPETENSI KEPRIBADIAN GURU \\ DALAM PEMBINAAN AKHLAK SISWA
}

(Studi Kasus di MTs Al-Ma'arif Brudu Sumobito Jombang)

Nurul Indana

Prodi Pendidikan Agama Islam, STIT Al Urwatul Wutsqo Jombang e-mail: nurulidana91@gmail.com

\author{
Rani Roifah \\ Prodi Pendidikan Agama Islam, STIT Al Urwatul Wutsqo Jombang \\ e-mail: raniroifah@gmail.com
}

\begin{abstract}
Teacher's personality competence is the most important factor for student learning success. Teachers become examples and role models in fostering and shaping students' morals. The purpose of this study was to: a description of the teacher's personality competence in moral development, a description of the process of character building for students at MTs Al Ma'arif Brudu Sumobito Jombang. The results showed that: the teacher's personality competence in building student morals, namely by reflecting the teacher's personality includes: a disciplined personality, being a good role model for students, having a good work ethic by carrying out the mandate and responsibilities as a teacher, being able to behave fair to students in the learning process, be assertive, have a consistent attitude in acting according to norms. The process of building student morals is carried out by various methods applied by the teacher, including: first, through exemplary by instilling discipline and student responsibility. Second, through good habituation by getting students accustomed to worshiping, smiling, greeting, greeting, and shaking hands, and helping each other. Third, give good advice or mani'shah to students. The fourth is to provide punishment with the aim of deterring students from repeating disgraceful acts.
\end{abstract}

Keywords: Teacher Personality Competence, Student Moral Development.

\section{PENDAHULUAN}

Era modern sekarang ini, Indonesia memerlukan sumber daya manusia dalam jumlah dan mutu yang memadai sebagai pendukung utama dalam pembangunan keberhasilan suatu Negara. Untuk memenuhi sumber daya manusia tersebut, pendidikan memiliki peran yang sangat penting. Pendidikan merupakan proses budaya yang mengangkat harkat dan martabat manusia sepanjang hayat. Hal ini termuat dalam Undang-Undang Nomor 20 Tahun 2003 Pasal 1 Ayat 1 tentang Sistem Pendidikan 
Nasional, yaitu "Pendidikan adalah usaha sadar dan terencana untuk mewujudkan suasana belajar dari proses pembelajaran agar siswa secara aktif mengembangkan potensi dirinya, memiliki kekuatan spiritual, keagamaan, pengendalian diri, kepribadian, kecerdasan, akhlak mulia, serta keterampilan yang diperlukan dirinya, masyarakat, bangsa dan Negara".

Ahmad Tafsir menjelaskan dalam bahwa pendidikan Islam adalah usaha sadar dan terencana yang struktur secara sistematis yang pengimplementasinya tidak hanya mengembangkan potensi manusia tetapi agar manusia itu menyadari posisinya sebagai khalifatullah fil ardhi, untuk menjadi manusia bertaqwa, beriman, berilmu, dan beramal shalih dalam konteks mendekatkan diri kepada Allah swt. Hal ini berkaitan dengan pembinaan akhlak siswa untuk mencapai kualitas akhlak yang baik pada diri setiap orang khususnya para generasi muda penerus di masa mendatang. Akhlak bagi siswa menempati tempat yang sangat penting, sebagai individu maupun masyarakat dan bangsa, sebab jatuh bangunnya suatu masyarakat tergantung bagaimana akhlaknya. ${ }^{1}$

Fakta lapangan kemerosotan moral atau akhlak pada siswa dimasa ini menjadi ironi yang menakutkan. Para pelajar yang masih berstatus remaja sangat rentan melakukan hal-hal yang negatif. Perilaku yang dilakukan para pelajar tersebut selain merugikan diri sendiri dan orang tua, juga mencemarkan lembaga pendidikan yang pada dasarnya ikut membentuk karakter dan kualitas akhlak dari setiap siswa. Hal ini menjadikan anggapan bahwa guru gagal dalam mendidik dan menjadi panutan bagi peserta didiknya ${ }^{2}$. Masalah akhlak seolah-olah menjadi kemutlakan guru Aqidah Akhlak, sebut saja masalah yang mendera bangsa ini, keterpurukan akhlak selalu saja yang disebut guru agama islam, ini salah satu konsekuensi terberat sebagai guru agama Islam, ketika seolah-olah akhlak menjadi tumpuan utama.

Guru adalah pendidik professional dengan tugas utama mendidik, mengajar, membimbing, mengarahkan, melatih, menilai dan mengevaluasi siswa pada pendidikan anak usia dini, jalur pendidikan formal, dasar dan menengah. Seorang guru merupakan salah satu komponen pendidikan yang mempunyai peran signifikan dalam dunia

\footnotetext{
1 Arisman. Pengaruh Kompetensi Kepribadian Guru Terhadap Motivasi Belajar Peserta Didik. Jurnal Diskursus Islam, (2018). 416.

2 A, Herian, Kompetensi Kepribadian Guru PAI dalam Membina Akhlak Peserta Didik. Jurnal Edu Riligia, (2017). 634.
} 
pendidikan. Guru dalam konteks kependidikan mempunyai peranan yang besar dan strategis. Kedudukan guru sangatlah urgen dalam dunia pendidikan sebab guru adalah sosok yang diberikan amanah oleh orang tua siswa untuk mendidik agar menjadi manusia seutuhnya. Guru juga menempati kedudukan yang terhormat dalam di masyarakat, kewibawaannya yang menyebabkan guru dihormati dan diterima. Oleh karena itu menjadi guru berdasarkan tuntutan hati nurani tidaklah semua orang dapat melaksanakannya. Guru dituntut mempunyai suatu pengabdian yang dedikasi, loyalitas, ikhlas, sehingga menciptakan anak didik yang dewasa, berakhlak dan berketrampilan.

Menurut Zakiah Dradjat menjadi guru harus memenuhi beberapa persyaratan diantaranya takwa kepada Allah SWT, berilmu, sehat jasmani dan berprilaku baik ${ }^{3}$. Maka guru harus memberikan contoh kepribadian dan akhlak yang baik untuk peserta didiknya, karena guru merupakan tauladan bagi siswa dalam sekolahan, masyarakat setempat yang nantinya sadar atau tidak sadar akan ditiru. Bagi guru pendidikan agama Islam, tugas yang diembannya meliputi tugas profesi, keaagamaan, kemanusiaan dan kemasyarakatan. $^{4}$

Tanggung jawab guru sangat berat, selain bertanggung jawab terhadap pembentukan pribadi anak yang sesuai dengan ajaran Islam, ia juga bertanggung jawab kepada Allah. Tugas dan tanggung jawab yang diemban merupakan amanah yang diterima atas dasar pilihannya untuk memangku jabatan guru. Seorang guru harus memenuhi persyaratan dalam mempertanggung jawabakan amanah tersebut, diantaranya mempunyai kompetensi sebagai salah satu faktor penting dalam pembinaan guru sebagai suatu jabatan profesi. Allah berfirman QS. Al- Isra': 36

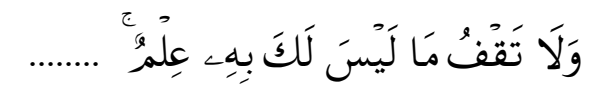

Artinya: Dan janganlah kamu mengikuti apa yang kamu tidak mempunyai pengetahuan tentangnya. ${ }^{5}$

Ayat tersebut memberikan penegasan untuk tidak mengikuti suatu hal apabila tidak memiliki pengetahuan tentang perkara tersebut. Sehingga demikian guru dituntut

3 A. Hawi, Kompetensi Pendidikan Agama Islam. (Jakarta: Raja Grafindo Persada. 2014). 11.

${ }^{4}$ Kunandar. Guru Profesional Implementasi Kurikulum Tingkatan Satuan Pendidikan dan Sukses dalam Sertifikasi Guru. Jakarta: Raja Grafindo. 2008).35

${ }^{5}$ Al Qur'an Terjemah Utsmani, $1998: 284$ 
untuk memiliki kompetensi khususnya guru pendidikan agama Islam ${ }^{6}$. Berdasarkan peraturan Menteri Agama Republik Indonesia Nomor 16 Tahun 2010 tentang Guru dan Tenaga Pendidikan pada Bab VI Pasal 16 menyebutkan guru Pendidikan Agama harus memiliki kompetensi dalam dirinya yaitu kompetensi kepribadian, kompetensi pedagogik, kompetensi profesional dan kompetensi sosial. Keempat kompetensi tersebut harus dimiliki guru, diminta ataupun tidak, mereka harus melakukannya secara tulus. Keempat kompetensi tersebut tidak berdiri sendiri melainkan saling berhubungan dan saling mempengaruhi, serta mendasari satu sama lain. Salah satu kompetensi yang terpenting dan harus dimiliki seorang guru dalam membina akhlak siswa adalah kompetensi kepribadian. Hal ini akan menjadi tolak ukur bagi siswa dalam kemerosotan moral yang terjadi masa kini.

Kompetensi kepribadian merupakan kemampuan personal yang mencerminkan kepribadian seorang guru. Dalam penjelasan pemerintah No 19 Tahun 2005 tentang Standar Pendidikan disebutkan bahwa kompetensi kepribadian guru adalah kemampuan kepribadian yang mantab, stabil, dewasa, arif dan bijaksana, berwibawa, berakhlak mulia, menjadi tauladan bagi siswa dan masyarakat, mengevaluasi kinerja sendiri, dan mengembangan diri secara berkelanjutan. Kompetensi ini memiliki peran dan fungsi yang sangat penting dalam membentuk kepribadian anak didik dalam rangka menyiapkan dan mengembangkan sumber daya manusia demi kemajuan bangsa dan Negara.

Pada realitanya masih banyak seorang guru masih tidak mencerminkan kepada hal yang seharusnya dapat menjadi contoh bagi setiap siswanya, namun guru tersebut tidak menunjukkan salah satu kompetensi guru yaitu kompetensi kepribadian yang baik $^{7}$. Karena kepribadian seorang guru akan mudah terlihat dan ditiru oleh setiap siswanya. Seorang guru yang menampilkan kepribadian yang tidak baik, maka kemungkinan besar siswa akan mencontoh prilaku seorang guru tersebut sehingga akan mempengaruhi prilaku seorang siswa dalam kehidupan sehari-harinya. Guru agama

\footnotetext{
${ }^{6}$ Kunandar. Guru Profesional Implementasi Kurikulum Tingkatan Satuan Pendidikan dan Sukses dalam Sertifikasi Guru. Jakarta: Raja Grafindo. 2008).35

7 A, Herian, Kompetensi Kepribadian Guru PAI dalam Membina Akhlak Peserta Didik. Jurnal Edu Riligia, (2017). 638.
} 
khususnya guru Aqidah Akhlak dan siswa memang dua figur manusia yang selalu hangat dibicarakan dan tidak akan pernah absen dari agenda masyarakat.

Menurut Zakiah Dradjat dalam bukunya Dahlan menjelaskan bahwa kepribadian itu akan menentukan apakah ia menjadi pendidik atau pembina yang baik bagi pelaksanaan pendidikan, karena dengan kepribadian seorang guru, siswa akan melihat dan merasakan secara langsung pengaruh pribadi dan keteladanan yang dimiliki gurunya. Kepribadian guru dapat berperan dalam pembentukan kepribadian peserta didik, karena salah satu sifat manusia secara umum adalah suka mencontoh/menirukan, termasuk mencontoh kepribadian gurunya. Maka kepribadian atau akhlak yang baik menjadi salah satu cakupan kepribadian seorang guru, memiliki pengaruh yang besar sekali pada akhlak anak didiknya. ${ }^{8}$

Akhlak adalah suatu keadaan bagi jiwa yang mendorong ia melakukan tindakantindakan dari keadaan itu tanpa melalui pikiran dan pertimbangan. Keadaan ini terbagi menjadi dua ada yang berasal dari tabiat aslinya, adapula diperoleh dari kebiasaan yang berulang-ulang ${ }^{9}$. Siswa-siswa akan mencontoh perkataan, perbuatan, dan semua gerak gerik seorang guru. Seorang guru harus memiliki kompetensi kepribadian yang baik, sebagai model yang tepat dalam pembelajaran dan pembinaan akhlak dengan menerapkan aspek-aspek beserta indikator kompetensi kepribadian guru profesioanal.

Pembinaan akhlak merupakan hal yang wajib diutamakan dalam proses pembelajaran manapun di lembaga pendidikannya, baik itu lembaga pendidikan asuhan dinas pendidikan maupun asuhan departemen agama, semuanya mengutamakan tercapainya kualitas akhlak siswa yang baik. Pembinaan akhlak merupakan awal dari terciptanya lingkungan masyarakat yang ideal, seperti terciptanya keadaan yang aman dan nyaman, suasana yang tentram dan damai, gotong-royong, tolong-menolong dan lain sebagainya.

Menurut Aly, dasar pembinaan akhlak dasar pembinaan akhlak tidak terlepas dari Al Qur'an dan Hadits yang memberi pandangan dan mengacu kehidupan dunia ini, maka dasarnya harus memilik petunjuk kepada pendidikan Islam. Al Qur'an sebagai dasar utama dalam membina akhlak, karena didalamnya menjelaskan tentang akhlak

${ }^{8}$ M. Dahlan R,. Menjadi Guru yang Bening Hati. (Yogyakarta: Deepublish.2018). 29

${ }_{9}$ Ahmad Susanto, Bimbingan dan Konseling di Sekolah. (Jakarta: Prenadamedia Group.2018).32 
yang dimiliki rosul ${ }^{10}$. Sebagaimana terdapat dalam firman Allah SWT. dalam surat AlAhzab ayat 21 sebagai berikut:

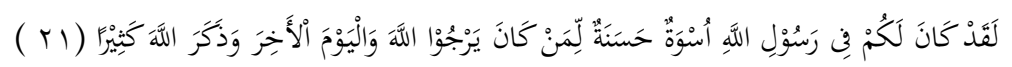

Artinya: Sesungguhnya telah ada pada (diri) Rosululloh itu ada suri tauladan yang baik bagimu (yaitu) bagi orang yang mengharap (rahmat) Allah dan (kedatangan) hari kiamat dan dia banyak menyebut Allah. ${ }^{11}$

Pada ayat ini Allah Swt. memberitahukan kepada hambaNya yang mukmin, bahwa pada diri Rasulullah Saw ini dengan penuh suri teladan yang harus di ikuti oleh orang-orang yang mengharapkan rahmat-Nya. Serta kedatangan hari kiamat kelak dan banyak/sering menyebut nama Allah Swt. dan beliau pun mempunyai akhlak yang mulia. Jadi sebagai pengikut nabi Muhammad, kita harus mencontoh akhlak Rosul sebagai panutan bagi hamba Allah yang mendambakan ${ }^{12}$.

Sebagai pengikut nabi Muhammad, kita harus mencontoh akhlak Rosul sebagai panutan bagi hamba Allah yang mendambakan. Oleh karena itu diharapkan seorang guru haruslah mampu membina dan menjadi teladan yang baik bagi anak didiknya, agar menjadi pribadi yang berakhlak mulia. Dengan adanya pola pendidikan Islam maka diharapkan pengembangan pola fikir anak akan mejadi generasi penerus bangsa yang Imtaq dan Iptek.

Kegiatan pembinan Akhlak dapat berhasil jika metode yang digunakan kompetensi yang diharapkan. Agar anak didik mencapai tujuan pembinaan yang terbentuknya insan kamil, maka metode harus mampu menerjemahkan ajaran-ajaran Islam secara konstektual. Seorang guru yang bijaksana tentu harus mencari metode yang efektif dengan menerapkan dasar-dasar pendidikan yang berpengaruh dalam mempersiapkan siswa secara mental, moral sosial, spiritual dan etos sosial.

Pembinaan akhlak di MTs Al Ma'arif Brudu dilaksanakan oleh emua pihak madrasah dan guru khususnya guru Aqidah Akhlak. Disana telah menerapkan berbagai metode, salah satunya adalah metode keteladanan, dimana kepribadian dan sikap yang dicerminkan guru yaitu telah berpakaian rapi dan sesuai aturan yang ada, datang lebih awal dari jam belajar dan mengajar, tegas dan disiplin saat pembelajaran dikelas. Guru

\footnotetext{
${ }^{10}$ H. N. Aly, Ilmu Pendidikan Islam. (Jakarta: Rineka Cipta.2001).17

${ }^{11}$ Al Qur'an Terjemah Utsmani, $1998: 420$

${ }^{12}$ H. N. Aly, Ilmu Pendidikan Islam. (Jakarta: Rineka Cipta.2001).16
} 
Aqidah Akhlak disana juga membina siswa-siswanya melaksanakan kegiatan keagamaan yang telah di program oleh madrasah sebagai penerapan pembiasaan keagamaan. Oleh kerena itu MTs Al-Ma'arif Brudu mencetak lulusan-lulusan yang terbaik dalam bidang agama, misalnya siswa hafal yaasin, tahlil, juz 30, serta siswa terbiasa berakhlak mulia misalnya sopan santun, senyum, sapa salam dan berjabat tangan, menghormati guru, jujur, disiplin, tanggung jawab sebagai siswa dengan melaksanakan tata tertib di madrasah.

Berdasarkan fakta-fakta di atas, telah banyak peneliti yang meneliti tentang kompetensi kepribadian guru yang masih kurang optimal dalam pembinaan akhlak siswa, yaitu masih terdapat guru yang kurang tegas dan displin kepada siswanya dalam pembelajaran. Karena di era modern ini akhlak siswa semakin rentan dalam hal negatif adanya pengaruh penyalahgunaan media sosial. Oleh karena itu seorang guru agama khususnya guru Aqidah Akhlak harus mampu meningkatkan pembinaan akhlak siswa yang didasarkan oleh ilmu agama melalui komptensi kepribadian guru. Berangkat dari permasalahan tersebut maka peneliti tertarik untuk mengadakan penelitian terkait pentingnya kompetensi kepribadian dalam pembinaan akhlak siswa melalui pembiasaan melaksanakan perbuatan yang diajarkan oleh Rasulullah.

\section{PEMBAHASAN}

A. Kompetensi Kepribadian Guru Aqidah Akhlak Dalam Membina Akhlak Siswa di MTs Al Ma'arif Brudu

Kompetensi kepribadian merupakan salah satu jenis kompetensi yang perlu dikuasi guru, selain kompetensi sosial, professional dan pedagogik. Kompetensi kepribadian yang dimiliki guru Aqidah Akhlak di MTs Al Ma'arif Brudu di sudah memenuhi aspek-aspek kepribadian guru, antara lain :

1. Kepribadian mantab dan stabil

Kepribadian mantab dan stabil merupakan sikap seorang guru professional yang sangat perlu dan dibutuhkan dalam menjalankan profesinya. Sebab guru yang memiliki sikap gampang berubah dan tidak ada pendirian, pasti tidak akan tahan dalam menjalankan pekerjaannya, serta tidak mampu membina akhlak anak didiknya. 
Guru Aqidah Akhlak di MTs Al MAa'arif Brudu sudah memiliki sikap kepribadian mantab dan stabil dengan kosisten dalam ucapan dan perbuatan diantaranya: guru Aqidah Akhlak konsisten melaksanakan tata tertib di madrasah dengan datang tepat waktu, berpakaian rapi dan disiplin sesuai ketentuan madrasah dan syari'at Islam, mengawali pembelajaran dengan berdo'a, menghormati sesama guru dan siswa dengan berbicara sopan santun. menghargai perbedaan siswa dengan tidak membeda-bedakan.

Hal ini sesuai dengan teori yang dikemukakan Mulyasa dalam bukunya "Uji Kompetensi dan Penilaian Kinerja Guru" megatakan bahwa seorang guru agar dapat melaksanakan tugasnya dengan baik, harus memiliki kepribadian yang mantab dan stabil. Hal ini penting karena banyak masalah pendidikan yang disebabkan oleh faktor kepribadian guru yang kurang mantab dan stabil. Kondisi yang demikian sering membuat guru melakukan tindakan-tindakan yang tidak professional, tidak senonoh yang merusak citra dan martabat guru. Kepribadian mantab dan stabil ini menekankan pada tiga hal yang menjadi landasan kepribadiannya, yakni kebenaran, tanggung jawab dan kehormatan. Adapun indikator kepribadian yang mantap dan stabil itu diantaranya: 1) bertindak sesuai dengan norma hukum, 2) bertindak sesuai dengan norma sosial, 3) bangga sebagai guru, dan 4) memiliki konsistensi dalam bertindak sesuai norma. ${ }^{13}$

Irjus Indrawan, mengemukakan teori dalam bukunya "Guru Sebagai Agen Perubahan" menjelaskan bahwa kepribadian yang mantab dan stabil dicirikan dengan tindakan yang sesuai dengan norma hukum dan sosial, rasa bangga sebagai pendidik dan memiliki konsistensi dalam bertindak sesuai dengan norma-norma yang ada. Selain itu kemantapan dan integritas pribadi dalam bekerja hendaknya menjadi karakteristik pribadi seorang guru. kemantapan dan integritas pribadi tidak bisa terwujud dengan sendirinya, melainkan tumbuh melalui proses belajar yang sengaja diciptakan. ${ }^{14}$

a. Kepribadian Dewasa

${ }^{13}$ E. Mulyasa, Uji Kompetensi dan Penilaian Kinerja Guru. (Bandung: PT. Remaja Rosdakarya. 2013).45

14 Irjus Indrawan, Guru Sebagi Agen Perubahan. (Klaten: Lakeisha. 2020).20 
Guru yang dewasa adalah guru yang mampu menahan dan mengendalikan diri dalam situasi yang dihadapi, mulai dari mengendalikan pikiran, bertutur kata, sikap dan menguasai emosi. Seperti yang dilakukan guru Aqidah Akhlak di MTs Al MAa'arif Brudu yang berhati-hati dalam bertindak dan mengendalikan emosi dalam menghadapi siswa yang selalu melanggar aturan di sekolah. Misalnya ketika anak-anak membuat kegaduhan dikelas, guru tersebut tidak langsung marah dan memukul, tetapi dinasehati dengan halus. Guru Aqidah Akhlak juga memiliki etos kerja yang baik yakni memiliki tanggung jawab dan amanah menjalankan tugasnya. Setiap hari guru Aqidah Akhlak menampilkan sikap rajin dan semangat mengajar, serta membina anak didiknya untuk memiliki akhlak mulia yakni bertanggung jawab melaksanakan kewajibannya seperti mengerjakan tugas sekolah.

Hal ini sesuai dengan teori yang dikemukakan Suprihatiningrum dalam bukunya "Guru Profesional" mengatakan bahwa, pada hakikatnya stabilitas dan kematangan emosi guru akan berkembang sejalan dengan pengalamannya, selama dia mau memanfaatkan pengalamanannya. Jadi tidak sekedar jumlah umur atau masa kerjanya yang bertambah, melainkan bertambahnya kemampuan memecahkan masalah atas dasar pengalaman masalalu. Untuk itu diperlukan latihan mental agar guru tidak mudah terbawa emosi. Sebab, jika guru marah akan mengakibatkan siswa takut dan ketakutan mengakibatkan kurangnya minat untuk mengikuti pelajaran serta rendahnya kosentrasi. ${ }^{15}$

Hal di atas juga sesuai dengan teori yang dikemukakan dikemukakan Mulyasa (2013) dalam bukunya "Uji Kompetensi dan Penilaian Kinerja Guru" mengatakan bahwa, indikator dari kepribadian yang dewasa yaitu: 1) menampilkan kemandirian dalam bertindak sebagai pendidik dan 2) memiliki etos kerja yang tinggi sebagai guru. Misalnya memiliki etos kerja yang baik, membuat perangkat pelajaran, tepat waktu datang kesekolah, berada di kelas ketika jam pelajaran berlangsung.

${ }^{15}$ J Suprihatiningrum,. Guru Profesional. (Jogjakarta: Ar-Ruzz Media. 2016). 20 
b. Kepribadian yang arif dan bijaksana

Kearifan merupakan sumber kebaikan, karena sifat arif dan bijaksana sangat berharga. Guru Aqidah Akhlak di Mts Al MAa'arif Brudu sudah mampu menampilkan berlaku adil kepada siswa, tidak membeda-bedakan atas kemampuan yang dimiliki siswa. Hal ini ditampilkan ketika guru Aqidah Akhlak memperlakukan siswa-siswa nya dengan sama diantaranya: 1) memperhatikan semua siswa nya, baik yang pandai maupun yang kurang pandai, 2) tetap membimbing bagi siswa yang kurang faham, 3) memberikan hukuman tanpa melihat status siswa tersebut, 4) memberikan hukuman pengurangan nilai terhadap siswa yang suka mencontek.

Hal ini sesuai dengan teori yang dikemukakan Mulyasa dalam bukunya "Uji Kompetensi dan Penilaian Kinerja Guru” megatakan bahwa Menurut Mulyasa, indikator kepribadian yang arif yaitu: 1) menampilkan tindakan yang didasarkan pada kemanfaatan peserta didik, sekolah dan masyarakat, dan 2) menunjukkan keterbukaan dalam berfikir dan bertindak. Misalnya bersifat ramah terhadap semua orang, bergaul dengan tutur kata yang baik dan tidak kasar, memiliki prilaku yang disegani dan diteladani oleh murid, guru, dam masyarakat. ${ }^{16}$

c. Kepribadian berwibawa

Kewibawaan adalah hal yang mutlak yang harus dimiliki seorang guru, khususnya guru Aqidah Akhlak dalam menghantarkan anak didiknya ke arah kedewasaan dalam proses pertumbuhan dan kepribadiannya. Guru Aqidah Akhlak di MTs Al Ma'arif Brudu sudah mampu mengimplementasikan nilai-nilai terutama yang diambil dari ajaran agama, misalnya berpakaian rapi dan profesional. Dimana guru Aqidah Akhlak mengupayakan tampilan berbusana sesuai dengan peraturan madrasah dan sesuai dengan cara berbusana Islami serta menjaga tutur bahasanya yang sopan santun. Contohnya guru laki-laki

${ }^{16}$ E. Mulyasa, Uji Kompetensi dan Penilaian Kinerja Guru. (Bandung: PT. Remaja Rosdakarya. 2013).122 
menggunakan peci dan guru perempuan menggunakan jilbab sesuai syari'at Islam.

Guru Aqidah Akhlak mampu menjaga gaya berbicaranya yang baik diantaranya: 1) berbicara dengan seperlunya, 2) berbicara yang bermanfaat, 3) tidak berbicara kotor, 4) tidak berbelit-belit dan tidak bergurau berlebihan terhadap siswa. Guru Aqidah Akhlak juga bersikap tegas dengan memberikan nasehat dan sanksi pada siswa yang melanggar peraturan madrasah. Ketegasan bukan berarti menunjukkan amarah atau kekerasan yang mencerminkan tindakan kriminalitas melainkan arti menunjukkan sikap santun dan mampu memberikan keputusan segera. Ketegasaan yang ditampilkan guru Aqidah Akhlak dapat menjadikan siswa menghormati dan menaati perintah yang diberikan.

Hal ini sesuai dengan teori yang dikemukakan Mulyasa dalam bukunya "Uji Kompetensi dan Penilaian Kinerja Guru" mengatakan bahwa indikator kepribadian yang berwibawa yaitu 1) memiliki perilaku yang berpengaruh positif terhadap siswa dan 2) memiliki perilaku yang disegani. Wibawa adalah pembawaan untuk dapat menguasai dan mempengaruhi, serta dihormati orang lain melalui sikap dan tingkah laku yang mengandung kepemimpinan dan penuh daya tarik. Berwibawa adalah mempunyai wibawa sehingga disegangi dan dipatuhi. Seorang guru harus selalu berusaha memilih dan melakukan perbuatan yang positif agar dapat mengangkat citara baik dan kewibawaannya, terutama di depan siswanya ${ }^{17}$

Nurdin mengemukakan dalam bukunya "Kiat Menjadi Guru Profesional" mengatakan bahwa kewibawaan yang dimiliki seoranng guru PAI akan membawa dan menghantarkan siswa kearah kedewasaan dalam proses pertumbuhan dan perkembangan kepribadiannya. Untuk membangun kewibawaan, seorang guru hendaknya memperhatikan beberapa hal berikut: kesesuaian antara perkataan dan perbuatan. jadilah orang yang pertama melakukan, dan berpegang pada nilai hakiki. ${ }^{18}$

${ }^{17}$ E. Mulyasa, Uji Kompetensi dan Penilaian Kinerja Guru. (Bandung: PT. Remaja Rosdakarya. 2013).45

18 M. Nurdin, Kiat Menjadi Guru Profesional. (Jogjakarta: Ar-Ruzz Media, 2008). 28 
d. Berakhlak mulia dan teladan

Akhlak mulia adalah prilaku yang didasarkan pada ajaran-ajaran agama, norma-norma sosial dan tidak bertentangan dengan adat dan istiadat masyarakat setempat. Guru harus memiliki akhlak mulia sebagai penanaman nilai-nilai bagi siswa. Seorang guru juga harus memiliki sikap dan kepribadian yang utuh untuk dijadikan suri tauladan bagi siswa.

Guru Aqidah Akhlak di MTs Al Ma’arif Brudu memiliki akhlak yang mulia dan memberikan keteladanan yang baik. Misalnya datang ke sekolah tidak pernah terlambat dan masuk ke dalam kelas selalu tepat waktu, mengucapkan salam, memiliki sikap dan tutur bahasa sopan santun, berpakaian rapi sesuai peraturan madrasah, menghormati orang lain. Guru Aqidah Akhlak juga selalu istiqomah dalam menjalankan ibadah sholat dhuha dan dhuhur dengan berjama'ah di masjid, berdo'a sebelum dan sesudah memulai pembelajaran dan mengikuti kegiatan keagamaan lainnya yang bersifat religius. Dari berbagai sikap dan prilaku yang di tampilkan guru Aqidah Akhlak, secara tidak langsung akan berpengaruh terhadap kepribadian siswa. Oleh karena itu guru Aqidah Akhlak selalu bersikap sabar dan terus berusaha yang terbaik dalam membimbing, membina dan menghadapi tingkah laku anak didiknya agar menjadi anak yang berakblakul karima

Hal ini sesuai dengan teori yang dikemukakan Mulyasa dalam bukunya "Uji Kompetensi dan Penilaian Kinerja Guru" megatakan bahwa indikator kepribadian berakhlak mulia yaitu: 1) bertindak sesuai norma religious (imtaq, jujur ikhlas, suka menolong) dan 2) memiliki prilaku yang diteladani peserta didik. Menurut teori Riswadi (2019) dalam bukunya "Kompetensi Profesional Guru” mengatakan bahwa kompetensi kepribadian guru dilandasi akhlak mulia tentu saja tumbuh dengan sendirinya begitu saja, tetapi memerlukan ijtihad yang mujahadah yakni usaha bersungguhsungguh, bekerja keras tanpa mengenal lelah dengan niat ibadah. Dalam hal ini, setiap guru harus merapatkan kembali barisannya, meluruskan niatnya bahwa menjadi guru bukan semata-mata untuk kepentingan 
duniawi, melainkan memperbaiki ikhtiar terutama berkaitan dengan tetap tawakal kepada Allah SWT. ${ }^{19}$

Susilo mengemukakan dalam bukunya "Kepribadian Seorang Guru, Apa dan Bagaimana" mengatakan bahwa penanaman nilai terhadap siswa tidak akan efektif apabila hanya diajarkan saja tanpa dicontohkan dengan kebiasaan diri. Seorang guru juga sebagai teladan bagi siswa, apa yang dilakukannya akan dapat sorotan siswa serta lingkungan sekitar. Oleh karena itu seorang guru harus memiliki perilaku yang diteladani siswa, artinya guru sebagai teladan bagi siswa-siswanya harus memiliki sikap dan kepribadian yang utuh yang dapat dijadikan tokoh panutan idola dalam seluruh segi kehidupan. ${ }^{20}$

\section{B. Proses pembinaan akhlak siswa di MTs Al Ma'arif Brudu}

Proses pembinaan akhlak yang dilakukan oleh pihak madrasah melalui upaya-upaya yang diterapkan oleh pendidik, khususnya pendidik Akidah Akhlak, Alquran Hadis, Fiqih dan SKI adalah dengan penerapan berbagai metode-metode. Berikut ini adalah berbagai metode yang diterapkan di MTs Al Ma'arif Brudu sebagai berikut :

1. Metode keteladanan

Proses pembinaan akhlak siswa yang dilakukan pihak Madrasah dan guru khususnya guru Aqidah Akhlak di MTs Al Ma'arif Brudu mencerminkan contoh sikap, perilaku, tutur bahasa yang baik bagi anak didiknya, diantaranya: 1) selalu disiplin waktu, 2) selalu mengikuti sholat dhuha dan dhuhur berjama'ah, 3) selalu mendampingi siswa melaksanakan kegiatan keagamaan setiap pagi yakni tahlilan dan mengaji yasin, 4) bertutur kata sopan santun, (5) selalu berdo'a sebelum dan sesudah pembelajaran. Hal ini secara sistematis membuat siswa akan merasakan bahwa dirinya memiliki figur dalam perkembangan kepribadiannya. Dimana segala perkataan dan tindakan guru akan menjadi pusat perhatian siswa dan mudah di tiru oleh siswa, diantaranya: 1) siswa disiplin waktu dan beribadah, 2) siswa bertanggung jawab dengan

${ }^{19}$ E. Mulyasa, Uji Kompetensi dan Penilaian Kinerja Guru. (Bandung: PT. Remaja Rosdakarya. 2013).45

20 A. B. Susilo, Kepribadian Seorang Guru, Apa dan Bagaimana. (Jakarta: Ganesa Baru Press. 2007). 
mengerjakan sesuatu dengan sendirinya tanpa diperintah, 3) siswa bertutur kata sopan santun.

Hal ini sudah sesuai dengan teori yang mengatakan bahwa metode teladan diberikan dalam bentuk prilaku terpuji guru sehari-hari, baik di depan siswa maupun dibelakangnya, karena pribadi guru bagi siswa adalah digugu dan ditiru. Dan perlu diingat bahwa keteladanan siswa dalam menjalankan perintah, larangan dan nasihat guru akan lebih tinggi apabila guru juga melaksanakan apa yang dikatakannya. Sebagaimana terdapat dalam firman Allah SWT. dalam surat $\mathrm{Al}$-Ahzab ayat 21 sebagai berikut:

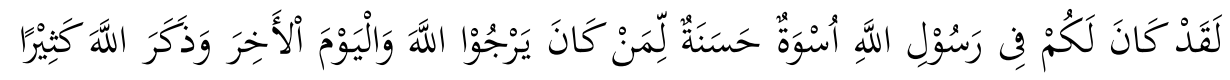

Artinya: Sesungguhnya telah ada pada (diri) Rosululloh itu ada suri tauladan yang baik bagimu (yaitu) bagi orang yang mengharap (rahmat) Allah dan (kedatangan) hari kiamat dan dia banyak menyebut Allah. ${ }^{21}$

Pada ayat di atas, Allah Swt. memberitahukan kepada hamba-Nya yang mukmin, bahwa pada diri Rasulullah Saw ini dengan penuh suri teladan yang harus di ikuti oleh orang-orang yang mengharapkan rahmat-Nya. Serta kedatangan hari kiamat kelak dan banyak/sering menyebut nama Allah Swt. Dan beliau pun mempunyai akhlak yang mulia. Jadi sebagai pengikut nabi Muhammad, kita harus mencontoh akhlak Rosul sebagai panutan bagi hamba Allah yang mendambakan.

Akbar mengemukakan dalam bukunya "Metode Belajar Anak" menjelaskan bahwa pelaksanaan metode keteladanan lebih mudah dilakukan karena guru sebagai contoh yang baik dalam segala hal. Keteladanan para guru tersebut antara lain: 1) guru memberi contoh dan bertutur kata yang baik dengan mengawali segala kegiatan dengan bacaan "basmallah" dan mengakhiri dengan bacaan "bamdalab”. 2) bertingkah laku dengan member keteladanan kejujuran, kasih sayang, ibadah dan lainnya. 3) bersikap baik dengan senyum dan salam. ${ }^{22}$

a. Metode pembiasaan

${ }^{21}$ Al Qur'an Terjemah Utsmani, 1998 : 420

22 E. Akbar, Metode Belajar Anak Usia Dini. (Jakarta: Kencana. 2019). 40 
Proses pembinaan akhlak dengan metode pembiasaan sudah sesuai apa yang telah diajarkan oleh Nabi Muhammad saw. Diantaranya Sebelum pembelajaran dimulai, madrasah memiliki pembiasaan kegiatan keagamaan yakni mengaji yaasin, tahlil, sholat dhuha dimasjid serta tausiab dari kepala madrasah. Setiap hari jum'at melaksanakan amal sholeh seperti kerja bakti membersihkan masjid, dan bersedekah membantu kerabat yang mengalami kesusahan, berziarah ke makam pendiri yayasan Mamba'ul Ma'arif. Semua kegiatan pembiasaan keagaaman untuk melatih siswa secara konsisten menjadikan kebiasaan baik yang sulit ditinggalkan dikemudian hari, diantaranya terbiasa beribadah kepada Allah dengan ikhlas melaksanakan sholat dhuha, sholat dhuhur berjama'ah, mengaji dan amal sholeh lainnya, serta agar siswa terbiasa mencerminkan akhlak mulia sesama manusia dengan bersikap sopan santun dan melaksanakan tanggung jawab sebagai siswa, saling tolong menolong, dan menghormati orang lain.

Metode pembiasaan akhlak bagi siswa MTs Al Ma'arif Brudu tidak hanya pembiasaan taat dengan Allah tetapi juga kepada sesama manusia. Hal ini sesuai degan teori Saehudin dalam bukunya yang berjudul "Hadits Pendidikan" mengatakan bahwa pembiasaan itu dilakukan berkali-kali agar melekat dalam jiwa peserta didik, seperti sholat berjamaah, mengucapkan salam kepada seluruh warga sekolah, berjabat tangan, bertutur kata yang sopan dan sebagainya. Perlu kita ketahui bahwasanya suatu perbuatan yang menjadi kebiasaan sukar untuk ditinggalkan. Dalam hati terasa sebagai suatu kewajiban, yang mana apabila ditinggalkan akan mengakibatkan resah dihati. ${ }^{23}$

M. Quraish Shihab mengemukakan teori dalam bukunya "Tafsir AlMisbah, Pesan, Kesan dan keserasian Al Qur'an" menjelaskan bahwa metode pembiasaan haruslah diupayakan dengan sungguh-sungguh agar dapat menumbuhkan hasil yang ideal ${ }^{24}$. Hal ini sebagaimana firman Allah SWT dalam surat An-Najm: 39

23 A. I Saehudin,. Hadis Pendidikan. (Bandung: Humaniora.2000), 30

${ }^{24}$ M. Q, Shihab,. Tafsir Al Misbah. (Jakarta: Lentera Hati.2002).34 


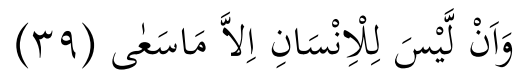

Artinya: "Dan bahwasanya seorang manusia tiada memperoleh selain apa yang telah diusahakannya"25

M. Quraish Shihab memberikan penjelasan tentang ayat tersebut yaitu" seorang manusia tidak memiliki selain apa yang telah diusahaknnya secara bersungguh-sungguh". Demikian pentingnya metode pembiasaan bagi perkembangan ibadah anak, sehinga Al-Qur an juga memberikan pendidikan tentang pembiasaan. Metode pembasaan yang di contohkan oleh Al-Qurean ini dapat dilihat dalam kasus menghilangkan kebiasaan meminum khamar misalnya. Dalam hal tersebut Allah SWT tidak langsung memberikan larangan meminum khamar akan tetapi melalui beberapa tahapan. Hal ini agar kebiasaan meminum khamar tidak lagi dilaksanakan dan agar lebih mudah untuk menghindarinya karena tidak langsung di haramkan. Jadi metode pembiasaan harus dilakukan secara bertahap-tahap dan sedikit memaksa untuk melakukan hal yang baik.

b. Metode Nasihat atau Mau'izhah

Metode pemberian nasehat guru Aqidah Akhlak MTs Al Ma'arif Brudu diberikan sesuai dengan situasi dan kondisi untuk mengetuk jiwa siswa melalui pintunya yang tepat. Guru Aqidah Akhlak dalam penerapan metode nasehat atau Man'izhah dilakukan dengan cara memberikan mengingatkan, mengajak dan mengarahkan disertai penjelasan tentaing baik dan buruknya sesuatu. Contohnya mendorong dan memotivasi siswasiswi nya untuk hidup bersih setiap hari agar mengajarkan siswa meningkatkan keimanannya dan menjalankan perintah Allah. Selain itu guru Aqidah Akhlak selalu memberikan nasehat ketika ada siswa yang melakukan akhlak yang tercela dengan cara arif, bijaksana, lemah lembut, dan mampu menyentuh hati siswa. Sehingga siswa tersebut menerapkan nasehat yang diberikan dalam kehidupan sehari-hari. Pemberian nasehat ini bertujuan untuk mengarahkan siswa untuk menerapkan kebaikan

${ }^{25}$ Al Qur'an Terjemah Utsmani, 1998 : 527 
kebenaran dalam kehidupan sehari-hari dan menghindari perbuatan tercela.

Sebagaimana yang dikemukakan oleh Arifin (2018) dalam bukunya yang berjudul "Pemikiran emas para tokoh pendidikan Islam" mengatakan bahwa metode nasihat atau mau'izhah adalah pemberitahuan seseoarang terhadap sesuatu yang baik agar ia dapat melakukannya dan menginformasikan sesuatu yang buruk agar tidak mengerjakannya. Nasihat atau man'iz̧ hah adalah metode yang seringkali digunakan oleh AlGhazali dalam mendidik, membina, dan membimbing para muridnya.

Gunawan mengemukakan teori dalam bukunya "Pendidikan Karakter Konsep dan Implementasi" menjelaskan bahwa nasihat atau mau'izhah adalah memberi pelajaran akhlak terpuji serta memotivasi pelaksanaannya dan menjelaskan akhlak tercela serta memperingatkan nya atau meningkatkan kebaikan dengan apa-apa yang melembutkan hati. Sebagaimana Allah SWT telah memerintahkan dalam firmanNya Q.S An-Nahl ayat 125:

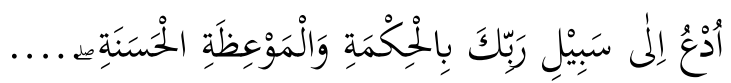

Artinya: "Serulah (manusia) kepada jalan Tuhan-mu dengan hikmah dan pelajaran yang baik" 26

c. Metode hukuman

Proses pembinaan akhlak siswa yang dilakukan guru Aqidah Akhlak dalam metode hukuman di MTs Al Ma'arif brudu telah dilaksanakan ketika mendapati siswa yang melanggar peraturan dan berkelakuan menyimpang. Hal ini guru Aqidah Akhlak tidak langsung memberikan hukuman, tetapi memberikan teladan dan nasehat terlebih dahulu, apabila tidak mampu dengan nasehat, maka guru Aqidah Akhlak mengambil tindakan yang terakhir yakni hukuman. Seperti ketika siswa membuat gaduh saat jam pelajaran guru harus memberikan nasehat terlebih dahulu, apabila tetap membuat kegaduhan, guru boleh menghukumnya dengan cara yang mengandung manfaat.

${ }^{26}$ Al Qur'an Terjemah Utsmani, 1998 : 281 
Hal di atas sesuai apa yang dikemukakan oleh Saehudin (2020) dalam bukunya yang berjudul "Hadits Pendidikan" bahwa, metode hukuman sebenarnya tidak mutlak diperlukan. Ada orang-orang yang hanya teladan dan nasihat saja sudah cukup,tidak perlu lagi hukuman dalam hidupnya. Diantara mereka ada yang perlu sekali-kali dikerasi, tetapi hukuman bukan tindakan pertama kali terbayang oleh seorang pendidik, dan tidak pula cara yang di dahulukan. Sebagaimana Allah berfirman dalam surah al Isra': 7

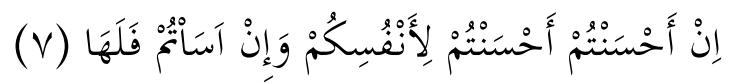

Artinya: "Tika kamu berbuat baik (berarti) kamu berbuat baik bagi dirimu sendiri dan jika kamu berbuat jabat maka (kejahatan) itu bagi drimu sendiri "27

Ayat di atas dapat dipahami bahwasanya setiap perbuatan pasti ada konsekuensinya, baik itu positif maupun negatif. Berdasarkan kenyataan yang ada, manusia tidak sama seluruhnya dalam berbagai hal, sehingga dalam pendidikan dan pembinaan akhlak perlu adanya hukuman dalam penerapannya, bagi orang-orang yang keras dan tidak cukup diberikan teladan dan nasehat. Jadi, dalam kenyataannya metode hukuman ini dilakukan jika dalam penggunaan metode selain hukuman dirasa sudah tidak mengalami perubahan, maka seorang guru memilih jalan terakhir menggunakan metode hukuman, namun hukuman yang dilakukan bukan berupa fisik, melainkan hanya sekedar memiliki efek jera dan bukan memiliki maksud untuk balas dendam maupun perasaan sentimen terhadap anak didiknya, atau hukuman yang bernilai untuk mendidik jika keteladanan dan nasehat tidak diterapkan oleh siswa.

\section{KESIMPULAN}

Kompetensi kepribadian guru Aqidah Akhlak dalam pembinaan akhlak mencerminkan sikap dan kepribadian yang baik meliputi: kepribadian yang disiplin, menjadi teladan yang baik bagi siswa, memiliki etos kerja yang baik dengan menjalankan amanah dan tanggung jawab sebagai seorang guru, mampu berprilaku adil

${ }^{27}$ Al Qur'an Terjemah Utsmani, $1998: 282$ 
kepada siswa dalam proses pembelajaran, bersikap tegas, sabar dan memiliki sikap konsisten dalam bertindak sesuai norma. Dengan kepribadian guru yang baik, maka pasti akan membentuk akhlak siswa yang mulia. Proses pembinaan akhlak siswa dilakukan oleh pihak madrasah dan guru khususnya guru Aqidah Akhlak agar menanamkan akhlak yang baik bagi siswa. Upaya-upaya yang dilakukan guru Aqidah Akhlak yaitu dengan berbagai penerapan metode diantaranya: (1) melalui metode keteladanan dengan cara menanamkan kedisiplinan dan tanggung jawab siswa, (2) melalui metode pembiasaan yang baik dengan cara membiasakan siswa untuk terbiasa beribadah, mengucapkan senyum, sapa, salam, dan berjabat tangan, saling tolong menolong, (3) metode memberikan nasehat, dimana siswa akan menghindari perbuatan tercela dan melakukan perbuatan yang terpuji dan (4) metode memberikan hukuman yang bertujuan siswa akan jera tidak mengulangi perbuatan yang salah. Sehingga proses pembinaan akhlak yang dilakukan oleh pihak madrasah untuk menanamkan perilaku-perilaku yang baik dari diri siswa selama di lingkungan madrasah dinilai cukup baik, Hal tersebut dibuktikan dari akhlak mulia siswa yang ditampilkan selama di madrasah, diantaranya: siswa melaksanakan tanggung jawab sebagai siswa dengan disiplin datang tepat waktu, berpakaian rapi, mengerjakan tugas yang di berikan guru, melaksanakan tata tertib dengan baik. Selain itu siswa melaksanakan kebiasaan beribadah, berprilaku sopan santun dan saling tolong menolong. Semua perkembangan prilaku siswa juga dibuktikan dengan catatan dan laporan dari para pendidik dan guru kesiswaan kepada kepala madrasah.

\section{DAFTAR PUSTAKA}

Akbar, E, Metode Belajar Anak Usia Dini. Jakarta: Kencana. 2019.

Al Qur'an Terjemah Utsmani, 1998

Aly, H. N. Ilmu Pendidikan Islam. Jakarta: Rineka Cipta.2001.

Arisman. Pengaruh Kompetensi Kepribadian Guru Terhadap Motivasi Belajar Peserta Didik. Jurnal Diskursus Islam, 2018.

Dahlan R, M. Menjadi Guru yang Bening Hati. Yogyakarta: Deepublish.2018.

Hawi, A, Kompetensi Pendidikan Agama Islam. Jakarta: Raja Grafindo Persada. 2014.

Herian, A, Kompetensi Kepribadian Guru PAI dalam Membina Akhlak Peserta Didik. Jurnal Edu Riligia, 2017. 
Indrawan, Irjus, Guru Sebagi Agen Perubahan. Klaten: Lakeisha. 2020.

Kunandar. Guru Profesional Implementasi Kurikulum Tingkatan Satuan Pendidikan dan Sukses dalam Sertifikasi Guru. Jakarta: Raja Grafindo. 2008

Mulyasa, E., Uji Kompetensi dan Penilaian Kinerja Guru. Bandung: Remaja Rosdakarya. 2013.

Nurdin, M. Kiat Menjadi Guru Profesional. Jogjakarta: Ar-Ruzz Media, 2008.

Saehudin, A. I. Hadis Pendidikan. Bandung: Humaniora.2000.

Shihab, M. Q,. Tafsir Al Misbah. Jakarta: Lentera Hati.2002.

Suprihatiningrum, J. Guru Profesional. Jogjakarta: Ar-Ruzz Media. 2016.

Susanto, Ahmad, Bimbingan dan Konseling di Sekolah. Jakarta: Prenadamedia Group.2018

Susilo, A. B. Kepribadian Seorang Guru, Apa dan Bagaimana. Jakarta: Ganesa Baru Press. 2007. 